JKKP: Jurnal Kesejahteraan Keluarga dan Pendidikan

http://doi.org/10.21009/JKKP

DOI: doi.org/10.21009/JKKP.022.08

E-ISSN: 2597-4521

\title{
Penumbuhan B udi Pekerti di Sekolah Melalui Implementasi Kurikulum 2013
}

\author{
Siti Istiningsih \\ Email: ningistie@yahoo.co.id \\ P rodiP endidikan Guru S ek olah Dasar, \\ FKIP -Universitas Mataram
}

\begin{abstract}
Abstrak
Tujuan dari penulisan ini adalah untuk mendeskripsikan program penumbuhan budi pekerti siswa sekolah melalui implementasi kurikulum 2013. Latar belakang dari program penumbuhan budi pekerti adalah masih terabaikannya implementasi nilai-nilai dasar kemanusiaan yang berakar dari Pancasila. Serta masih terbatas pemahaman nilai dalam tataran konseptual, belum terwujud menjadi nilai aktual dengan cara yang menyenangkan di lingkungan sekolah, keluarga dan masyarakat. Pada implementasi kurikulum 2013, penumbuhan budi pekerti pada siswa sekolah dapat dilaksanakan melalui kegiatan intrakurikuler, ekstrakulikuler dan nonkurikuler. Peranan guru dalam penumpuhan budi pekerti di sekolah sangat diharapkan sebagai contoh keteladanan siswa untuk membiasakan diri dalam bersikap dan berperilaku yang baik sesuai dengan tatanan dan nilai-nilai luhur budaya dan pancasila.
\end{abstract}

Kata Kunci: Budi Pekerti, Sekolah, Kurikulum 2013

\section{Growth Character in School by Implementation of C urriculum 2013}

\begin{abstract}
This study aim to describe growth character's program of student by implementation curricullum 2013. The back ground is still neglected humanitarian basic values implementation who rooted from Pancasila. And then still limited value comprehension in conceptual's level, not materialized to be actual value with a fun way in surroundings of school, family, and society. The implementation curriculum 2013, growth character in student could it be activity (intracurricular, extracurricular, and noncurricular). Teacher in growth character at school is expected as exemplary student to get one's teeth in attitude and behavior are good in accordance with order and cultural values and Pancasila.
\end{abstract}

Keyword: Character, School, Curriculum 2013

\section{PENDAHULUAN}

Peradaban akan menurun apabila terjadi demoralisasi pada masyarakatnya. Faktor moral dan akhlak adalah hal yang dapat digunakan untuk membangun masyarakat yang tertib, aman dan sejahtera. Hal tersebut merupakan salah satu kewajiban utama yang harus dijalankan oleh orang tua 
kepada anak-anak kita. Nilai-nilai budi pekerti yang ditanamkan akan membentuk akhlak mulia yang merupakan fondasi penting bagi terbentuknya sebyah tatanan masyarakat yang beradab dan sejahtera.

Indonesia saat ini sedang menghadapi masalah berat yang harus dilalui, yaitu terjadinya krisis multidimensi yang berkepanjangan. Masalah ini sebetulnya mengakar pada menurunnya kualitas moral bangsa yang dicirikan oleh membudayanya praktek KKN, konflik,antar etnis, agama, politisi, kenakalan remaja, meningkatnya kriminalitas, menurunnya etos kerja, dan sebagainya. Budayabudaya tersebut adalah penyebab utama negara kita sulit untuk bangkit dari krisis ini.

Karakter yang berkualitas perlu dibentuk dan dibina sejak usia dini. Usia dini merupakan masa kritis bagi pembentukan karakter seseorang. Banyak pakar mengatakan bahwa kegalalan penanaman karakter sejak usia dini, akan membentuk pribadi yang bermasalah dimasa dewasanya kelak. Selain itu, menanamkan moral kepada generasi muda adalah usaha yang strategis. Oleh karena itu, penanaman moral melalui penumbuhan budi pekerti sedini mungkin kepada anak-anak adalah kunci utama untuk membangun bangsa.

Penumbuhan Budi Pekerti sesuai dengan Peraturan Menteri Pendidikan dan Kebudayaan I No 21 Tahun 2015 dengan melaksanakan kegiatan pembiasaan sikap dan perilaku positif di sekolah yang dimulai berjenjang dari mulai Sekolah, SMP, SMA/SMK dan sekolah jalur pendidikan khusus dimulai sejak dari masa orientasi peserta didik baru sampai dengan kelulusan. Pembentukan karakter melalui penumbuhan budi pekerti merupakan salah satu tujuan pendidikan nasional. Pasal I UU Sisdiknas tahun 2003 menyatakan bahwa di antara tujuan pendidikan nasional adalah mengembangkan potensi peserta didik untuk memiliki kecerdasan, kepribadian dan akhlak mulia.Amanah UU Sisdiknas tahun 2003 itu bermaksud agar pendidikan tidak hanya membentuk insan Indonesia yang cerdas, namun juga berkepribadian atau berkarakter. Sehingga akan lahir generasi bangsa yang tumbuh berkembang dengan karakter yang memiliki nilai-nilai luhur bangsa serta agama.

Bersamaan dengan implementasi Kurikulum 2013 dan sesuai dengan tujuan umum pendidikan nasional yang dituangkan dalam Undang-Undang No.20, Tahun 2003. Pasal 3 menyebutkan, "Pendidikan nasional berfungsi mengembangkan kemampuan dan membentuk watak serta peradaban bangsa yang bermartabat dalam rangka mencerdaskan kehidupan bangsa, bertujuan untuk berkembangnya potensi peserta didik agar menjadi manusia yang beriman dan bertakwa kepada Tuhan Yang Maha Esa, berakhlak mulia, sehat, berilmu, cakap, kreatif, mandiri, dan menjadi warga negara yang demokratis serta bertanggung jawab. Sebagai acuan terlaksananya pendidikan nasional, kurikulum adalah salah satu faktor penting yang dapat mempengaruhi kesuksesan proses pembelajaran. Kurikulum 2013 merupakan bentuk program kegiatan pendidikan yang mengakomodasi proses pembelajaran untuk membentuk kompetensi dari ranah religi atau ketuhanan, ranah pengetahuan, ranah sosial dan ranah keterampilan. Pendidikan sikap dan moral tertanam dalam setiap kegiatan pembelajaran tematik yang ada di dalamya sehingga kegiatan pembelajaran dapat terintegrasi secara menyeluruh.

Menurut Anies Baswedan, (2015), Penumbuhan budi pekerti juga dapat diartikan sebagai suatu sistem penanaman nilai-nilai moral kepada warga sekolah yang meliputi komponen pengetahuan, kesadaran atau kemauan, dan tindakan untuk melaksanakan nilai-nilai tersebut, baik terhadap Tuhan Yang Maha Esa (YME), diri sendiri, sesama, lingkungan, maupun kebangsaan sehingga menjadi manusia insan kamil. Dalam penumbuhan budi pekerti di sekolah, semua komponen (stak eholders) harus dilibatkan, termasuk komponen- komponen pendidikan itu sendiri, yaitu isi kurikulum, proses pembelajaran dan penilaian, kualitas hubungan, penanganan atau pengelolaan mata pelajaran, pengelolaan sekolah, pelaksanaan aktivitas atau kegiatan ko-kurikuler, pemberdayaan sarana prasarana, pembiayaan, dan ethos kerja seluruh warga dan lingkungan sekolah.

Penumbuhan Budi Pekerti adalah kegiatan pembiasaaan sikap dan perilaku positif di sekolah 
yang dimulai berjenjang dari mulai sekolah; untuk jenjang SMP, SMA, SMK dan sekolah pada jalur pendidikan khusus dimulai sejak dari masa orientasi peserta didik baru sampai dengan kelulusan, (Kemendikbud, 2015). Kerangka Dasar Kurikulum 2013 memuat arahan atau acuan atau tuntutan mengenai sejumlah prioritas yang perlu diakomodasi dalam kurikulum sebagai salah satu sumber daya pendidikan, yaitu kurikulum harus menjadi media untuk:

1. Transformasi Pilar Kehidupan Berbangsa dan Bernegara

Kurikulum mengarahkan kepada pendidik untuk membelajarkan peserta didik agar dapat memperkuat jati diri dan karakter dirinya dengan berdasarkan pada:

a. Pancasila sebagai falsafah, ideologi, dan dasar negara yang menjadi wahana perjuangan untuk membangun kehidupan bangsa dan negara yang adil, makmur, dan sejahtera;

b. Undang-Undang Dasar 1945 sebagai hukum dasar yang menjadi pegangan untuk mengatur penyelenggaraan bernegara;

c. Bhineka Tunggal Ika sebagai prinsip pengintegrasian keanekaragaman seluruh komponen bangsa yang terdiri atas perbedaan suku, agama, adat istiadat, dan kebudayaan; dan

d. Negara Kesatuan Republik Indonesia sebagai prinsip keutuhan teritori yang mengamankan bangsa dan negara dari gangguan konflik horizontal dan vertikal, separatis, sikap apatis, dan disintegrasi.

2. Internalisasi Nilai-Nilai Pembentuk Karakter Bangsa

Kurikulum mengarahkan kepada pendidik untuk membiasakan peserta didik agar dapat menginternalisasi nilai-nilai pembentuk karakter bangsa melalui seluruh aktivitas kurikuler. Pembentukkan karakter bangsa di sekolah bertujuan mengembangkan kemampuan peserta didik untuk memberikan keputusan baik-buruk, memelihara apa yang baik, dan mewujudkan kebaikan itu dalam kehidupan sehari-hari dengan sepenuh hati. Meskipun terdapat banyak jumlah nilai-nilai pembentuk karakter, namun untuk kepentingan pembentukkan karakter bangsa saat ini didasarkan pada nilai-nilai yang sudah teridentifikasi, antara lain: (1) religius, (2) jujur, (3) toleransi, (4) disiplin, (5) kerja keras, (6) kreatif, (7) mandiri, (8) demokratis, (9) rasa ingin tahu, (10) semangat kebangsaan, (11) cinta tanah air, (12) menghargai prestasi, (13) bersahabat/komunikatif, (14) cinta damai, (15) gemar membaca, (16) peduli lingkungan, (17) peduli sosial, dan (18) tanggung jawab.

Mengacu pada nilai-nilai tersebut, para pendidik dan tenaga kependidikan dapat menggali lagi nilai-nilai pembentuk karakter lainnya sesuai dengan kebutuhan, sehingga lebih memperkaya nilai-nilai yang sudah teridentifikasi sebelumnya. Dengan melalui pembiasaan, nilai-nilai pembentuk karakter tersebut dapat diinternalisasi oleh peserta didik, sehingga mereka diharapkan dapat menjadi tokoh masyarakat dan/atau pemimpin bangsa yang berkualitas tinggi di kemudian hari.

3. Pemberdayaan Potensi P es erta Didik Secara Berkarakteristik -Holistik

Kurikulum mengarahkan kepada pendidik untuk membelajarkan peserta didik agar dapat memiliki potensi yang diisi dengan nilai-nilai pembentuk karakter secara holistik. Pemberdayaan potensi tersebut mencakup empat dimensi, yaitu: (1) kemampuan olah hati; (2) kemampuan olah pikir; (3) kemampuan olah rasa; dan (4) kemampuan olah raga. Keempat dimensi kemampuan tersebut divisualisasikan sebagai berikut:

\section{METODE PENELITIAN}

Metode yang digunakan dalam penulisan artikel ini adalah metode kajian pustaka yaitu metode kajian dengan menggunakan informasi yang diperoleh dari suatu topik berrdasarkan literatur atau hasil enelitian oleh para ilmuwan atau pakar. 


\section{HASIL DAN PEMBAHASAN}

\section{Dasar Pertimbangan Penumbuhan Budi Pekerti di Sekolah}

Dasar pertimbangan dilaksanakannya penumbuhan budi pekerti adalah masih terabaikannya implementasi nilai-nilai dasar kemanusiaan yang berakar dari pancasila yang masih terbatas pada pemahaman nilai dalam tataran konseptual, belum sampai mewujud menjadi nilai aktual dengan cara yang menyenangkan di lingkungan sekolah, keluarga dan masyarakat, Bahwa setiap sekolah harus menjadi tempat yang nyaman dan inspiratif bagi siswa, guru, dan/atau tenaga kependidikan, bahwa pembiasaan sikap dan perilaku positif di sek olah merupakan cerminan dari nilai-nilai Pancasila dan harus menjadi bagian proses belajar dan budaya setiap sekolah, bahwa pendidikan karakter harus menjadi gerakan bersama yang melibatkan pemerintah, pemerintah daerah, masyarakat dan atau orang tua.

Pelaksanaan PBP didasarkan pada nilai-nilai dasar kebangsaan dan kemanusiaan yang meliputi pembiasaan untuk menumbuhkan:

a) Internalisasi sikap moral dan spiritual, yaitu mampu menghayati hubungan spiritual dengan Sang Pencipta yang diwujudkan dengan sikap moral untuk menghormati sesama mahluk hidup dan alam sekitar.

b) Keteguhan menjaga semangat kebangsaan dan kebhinekaan untuk merekatkan persatuan bangsa, yaitu mampu terbuka terhadap perbedaan bahasa, suku bangsa, agama, dan golongan, dipersatukan oleh keterhubungan untuk mewujudkan tindakan bersama sebagai satu bangsa, satu bahasa, satu tanah air Indonesia.

c) Interaksi sosial positif antara peserta didik dengan figur orang dewasa di lingkungan sekolah dan rumah, yaitu mampu menghormati guru, kepala sekolah, tenaga kependidikan, warga masyarakat di lingkungan sekolah dan orang tua.

d) Memelihara lingkungan sekolah, yaitu melakukan gotong royong untuk menjaga keamanan, ketertiban, kenyamanan, dan kebersihan lingkungan.

Jenis-jenis kegiatan penumbuhan budi pekerti yang dapat dilaksanakan di Sekolah sesuai dengan Kurikulum 2013 adalah: a) Jenis kegiatan yang mengandung nilai-nilai internalisasi sikap moral dan spiritual, b) Jenis kegiatan yang mengandung nilai keteguhan menjaga semangat kebangsaan dan kebhinekaan untuk merekatkan persatuan bangsa, c) Jenis kegiatan yang mengandung nilai memelihara lingkungan sekolah, d) Jenis kegiatan yang mengandung nilai interaksi sosial positif antar peserta didik, e) Jenis kegiatan yang mengandung nilai interaksi sosial positif antara peserta didik dengan figur orang dewasa, f) Jenis kegiatan yang mengandung nilai penghargaan terhadap keunikan potensi peserta didik untuk dikembangkan, g) Jenis kegiatan yang mengandung nilai penguatan peran orang tua dan unsur masyarakat yang terakit.

Seluruh pelaksanaan kegiatan penumbuhan budi pekerti bersifat kontekstual, yaitu disesuaikan dengan nilai-nilai muatan lokal daerah pada peserta didik sebagai upaya untuk memperkuat nilai-nilai kemanusiaan. Waktu pelaksanaan kegiatan PBP dapat dilakukan berdasarkan aktivitas harian, mingguan, bulanan, tengah tahunan, dan akhir tahun, dan penentuan waktunya dapat disesuaikan dengan konteks lokal di daerah masing-masing.

Dengan penumbuhan budi pekerti yang diterapkan secara sistematis dan berkelanjutan, seorang anak akan menjadi cerdas emosinya. Kecerdasan emosi ini adalah bekal penting dalam mempersiapkan anak menyongsong masa depan, karena seseorang akan lebih mudah dan berhasil menghadapi segala macam tantangan kehidupan, termasuk tantangan untuk berhasil secara akademis.

2. Pendidikan Budi Pekerti di S ek olah

Faktor kelurga sangat berperan dalam membentuk karakter anak. Namun kematangan emosi 
sosial ini selanjutnya sangat dipengaruhi oleh lingkungan sekolah sejak usia dini sampai usia remaja. Bahkan menurut Daniel Goleman, banyaknya orang tua yang gagal dalam mendidik anak-anak, kematangan, emosi sosial anak dapat dikoreksi dengan memberikan latihan pendidikan budi pekerti kepada anak-anak di sekolah terutama sejak usia dini.

Sekolah adalah tempat yang strategis untuk pendidikan budi pekerti karena anak-anak dari semua lapisan akan mengenyam pendidikan di sekolah. Selain itu, anak-anak menghabiskan sebagian besar waktunya di sekolah, sehingga apa yang didapatkannya di sekolah akan mempengaruhi pembentukan karakternya.

Indonesia belum mempunyai pendidikan karakter yang efektif untuk menjadikan bangsa Indonesia yang berkarakter (tercermin dari tingkah lakunya). Padahal ada beberapa mata pelajaran yang berisikan tentang pesan-pesan moral, misalnya pelajaran agama, kewarganegaraan, dan pancasila. Namun proses pembelajaran yang dilakukan adalah dengan pendekatan penghafalan (kognitif). Para siswa diharapkan dapat menguasai materi yang keberhasilannya diukur hanya dengan kemampuan anak menjawab soal ujian (terutama dengan pilihan berganda). Karena orientasinya hanyalah semata-mata hanya untuk memperoleh nilai bagus, maka bagaimana mata pelajaran dapat berdampak kepada perubahan perilaku, tidak pernah diperhatikan. Sehingga apa yang terjadi adalah kesenjangan antara pengetahuan moral (cognition) dan perilaku (action). Semua orang pasti mengetahui bahwa berbohong dan korupsi itu salah dan melanggar ketentuan agama, tetapi banyak sekali orang yang tetap melakukannya. Tujuan akhir dari pendidikan karakter melalui penumbuhan budi pekerti adalah bagaimana manusia dapat berperilaku sesuai dengan kaidah-kaidah moral.

Menurut Berman, iklim sekolah yang kondusif dan keterlibatan kepala sekolah dan para guru adalah faktor penentu dari ukuran keberhasilan interfensi pendidikan karakter di sekolah. Dukungan saran dan prasarana sekolah, hubungan antar murid, serta tingkat kesadaran kepala sekolah dan guru juga turut menyumbang bagi keberhasilan penumbuhan budi pekerti ini, disamping kemampuan diri sendiri (melalui motivasi, kreatifitas dan kepemimpinannya) yang mampu menyampaikan konsep karakter pada anak didiknya dengan baik.

3. Nilai-nilai Budi Pek erti yang Perlu Ditanamkan di S ek olah

Pada masyarakat yang heterogen dengan berbeda-beda latar belakang sosial budaya dan agama, adanya common values (nilai-nilai yang dijunjung tinggi bersama) sangat diperlukan. Nilai-nilai ini dapat menjadi perekat yang efektif sehingga akan tercipta relasi sosial yang harmonis, yaitu terjadinya rasa kebersamaan. Misalnya, adanya nilai kejujuran yang dijunjung tinggi maka akan membuat setiap orang percaya pada kelompok masyarakat lainnya, bahwa mereka tidak akan diambil haknya atau ditipu. Juga dengan adanya tanggung jawab, setiap orang akan menjalankan kewajibannya, sehingga hak semua orang dapat terpenuhi.

Ada beberapa nilai yang dianggap perlu untuk dijadikan fokus penumbuhan budi pekerti. Misalnya dalam deklarasi Aspen dihasilkan 6 nilai etik utama (core ethical values) yang disepakati untuk diajarkan dalam sistem pendidikan karakter (penumbuhan budi pekerti) di Amerika yang meliputi:

1. Dapat dipercaya

2. Memperlakukan orang lain dengan hormat

3. Bertanggung jawab

4. Adil

5. Kasih saying

6. Warga negara yang baik

Sedangkan IHF telah membuat konsep sembilan pilar karakter (budi pekerti) yang untuk dijadikan modul pendidikan karakter. Kesembilan plar ini adalah nilai-nilai yang bersifat universal yaitu (1) cinta Tuhan dan segenap ciptaanNya, (2) kemandirian dan tanggung jawab, (3) kejujuran/amanah, 
bijaksana, (4) hormat dan santun, (5) dermawan, suka menolong dan gotong royong, (6) percaya diri, kreatif dan pekerja keras, (7) kepemimpinan dan keadilan, (8) baik dan rendah hati, (9) toleransi, kedamaian, dan kesatuan, (Muchlas Samani, 2011)

4. Membangun Karak ter di sekolah Secara E fektif

Penumbuhan budi pekerti dalam pendidikan karakter harus mengandung nilai-nilai yang mengandung acuan nilai moral Lawrence Kohlberg adalah seorang yang paling berperan dalam menerapkan metode values clarification atau yang dikenal dengan moral dilemmas. Apabila seseorang sejak kecil tidak diberitahukan bekal standard moral yang dianggap baik atau buruk dan tidak berlatih untuk berlaku jujur, maka kapasitas untuk memilih "tidak mencuri" tidak dimiliki, sehingga dengan mudah dia mengambil keputusan untuk mencuri. Apabila ia mempunyai kapasitas di dalam dirinya untuk berlaku jujur, maka perasaan bimbang akan muncul, dan ia dapat memilih diantara dua tindakan "mancuri" dan "tidak mencuri".

Metode value clarification tidak membenarkan untuk mengajarkan standart dari moral, tetapi harus timbul dari dalam diri seseorang, seperti metode Socrates. Hal ini bukan berarti cara Socrates dengan argumentasi adalah salah, tetapi menurut William Kilpatrick, cara ini hanya tepat digunakan untuk orang dewasa atau orang yang mengetahui sebelumnya standart moral baik dan buruk. Bahkan menurut plato sebagai orang yang menguasai filsafat Socrates, metode argumentasi hanya dapat diberikan pada orang yang sudah dewasa atau diatas umur 30 tahun.

5. Penumbuhan Budi Pekerti yang Melibatkan Aspek Moral Knowing, Moral Feeling, dan Moral Action

Dalam penumbuhan budi pekerti Lickona menekankan pentingnya tiga komponen karakter yang baik yaitu moral knowing atau pengetahuan tentang moral, moral feeling atau perasaan tentang moral dan moral action atau perbuatan moral. Hal ini diperlukan agar siswa didik mampu memahami, merasakan dan mengerjakan sekaligus nilai-nilai kebijakan.

6. Penumbuhan Budi Pek erti secara Eksplisit dalam Implementasi Kurik ulum 2013

Salah satu kurikulum pendidikan karakter (budi pekerti) yang secara eksplisit dijalankan adalah metode pendidikan STAR (Stof, Think, Action, and Review) yang dikembangkan oleh J afferson Center for Caracter Education yang berkedudukan di California, Amerika Serikat. Metode ini hanya memerlukan waktu 10 sampai 15 menit sehari sebelum kelas dimulai. Anak-anak mendapatkan pendidikan karakter dengan intruksi yang diberikan guru sesuai dengan kurikulum yang tersedia, dengan menggunakan beberapa tema secara bergantian (be responsible, be on time, be nice, be a good listener, dan sebgainya). Dengan menggunakan metode ini murid-murid sekolah digiring untuk mengerti konsep-konsep dengan cara berdiskusi. Kekurangan dari metode ini adalah kurang melibatkan aspek loving dan action. Melalui program pembelajaran berbasis

Kurikulum 2013, penumbuhan budi pekerti dapat dilakukan dengan :

1. Menumbuhkan nilai-nilai Moral

Spiritual, menumbuhkan kesadaran moral dan spiritual dalam perilaku sehari-hari. Kegiatan wajib: guru dan peserta didik berdoa bersama sesuai dengan keyakinan masing-masing, sebelum dan sesudah hari pembelajaran, dipimpin oleh seorang peserta didik secara bergantian. Contoh-contoh pembiasaan baik yang dapat dilakukan oleh sekolah, $\mathrm{m}$ embiasakan untuk menunaikan ibadah bersama sesuai agama dan kepercayaannya baik dilakukan di sekolah maupun bersama masyarakat, membiasakan perayaan Hari Besar Keagamaan dengan kegiatan yang sederhana dan hikmat.

2. Menumbuh kembangkan Nilai-nilai

Kebangsaan dan Kebhinekan Menumbuhkan rasa cinta tanah air dan menerima keberagaman sebagai anugerah untuk bangsa Indonesia. Anugerah yang harus dirasakan dan disyukuri sehingga 
manfaatnya bisa terasa dalam kehidupan sehari-hari. Kegiatan Wajib: Melaksanakan upacara bendera setiap hari Senin dengan menggunakan seragam sekolah, Menyanyikan lagu bernuansa patriotik dan cinta tanah air baik lagu wajib nasional, lagu daerah maupun lagu-lagu terkini.

3. Mengembangkan interaksi positif antara peserta didik dengan guru dan orang tua.

Pendidikan adalah tanggung jawab bersama antara sekolah, peserta didik dan orangtua, interaksi positif antara tiga pihak tersebut dibutuhkan untuk membangun persepsi positif, saling pengertian dan saling dukung demi terwujudnya pendidikan yang efektif. Kegiatan Wajib; Melaksanakan pertemuan orangtua siswa pada setiap tahun ajaran baru untuk mensosialisasikan visi, aturan, materi dan capaian belajar siswa yang diharapkan dapat dukungan orang tua di rumah

4. Mengembangkan Interaksi Positif Antar Peserta Didik.

Peserta didik hadir di sekolah bukan hanya belajar akademik semata, tapi juga belajar bersosialisasi. Interaksi positif antar peserta didik akan mewujudkan pembelajaran dari rekan (peer learning) sekaligus membantu siswa untuk belajar bersosialisasi. Kegiatan Wajib: Membiasakan pertemuan di lingkungan sekolah dan/atau rumah untuk belajar kelompok yang diketahui oleh guru dan/atau orangtua. Contoh- contoh pembiasaan baik yang dapat dilakukan oleh sekolah adalah Gerakan kepedulian kepada sesama warga sekolah dengan menjenguk warga sekolah yang sedang mengalami musibah, seperti sakit, kematian, dan lainnya, membiasakan siswa saling membantu bila ada siswa yang sedang mengalami musibah atau kesusahan.

5. Merawat Diri dan Lingkungan Sekolah.

Lingkungan sekolah akan mempengaruhi warga sekolah baik dari aspek fisik, emosi, maupun kesehatannya. Karena itu penting bagi warga sekolah untuk menjaga keamanan, kenyamanan, ketertiban, kebersamaan dan kesehatan lingkungan sekolah serta diri. Kegiatan Wajib: Membiasakan kerja bakti membersihkan lingkungan sekolah dengan membentuk kelompok lintas kelas dan berbagi tugas sesuai usia dan kemampuan siswa. Membiasakan penggunaan sumber daya sekolah (air, listrik, telepon, dsb) secara efisien melalui berbagai kampanye kreatif dari dan oleh siswa, menyelenggarakan kantin yang memenuhi standar kesehatan, membangun budaya peserta didik untuk selalu menjaga kebersihan di bangkunya masing-masing sebagai bentuk tanggung jawab individu maupun kebersihan kelas dan lingkungan sekolah sebagi bentu tanggung jawab bersama.

6. Mengembangkan Potensi Diri Peserta Didik Secara Utuh.

Setiap siswa mempunyai potensi yang beragam. Sekolahmhendaknya memfasilitasi secara optimal, agar siswa bisa mengenali dan mengembangkan potensinya. Kegiatan penumbuhan budi pekerti di Sekolah merupakan kegiatan Wajib sejauh mana kegiatan dapat dilaksanakan dengan baik guna peningkatan pada kegiatan selanjutnya.

\section{KESIMPULAN}

Menggunakan waktu 15 meniit sebelum hari pembelajaran untuk membaca buku selain buku pelajaran, warga sekolah memanfaatkan waktu sebelum memulai hari pelajaran pada hari-hari tertentu untuk kegiatan oleh fisik seperti senam kesegaran jasmani, siswa melakukan kegiatan positif secara berkala sesuai dengan potensi dirinya.

6. Pelibatkan Orangtua dan Masyarakat di Sekolah.

Pendidikan adalah tanggung jawab bersama. Karena itu, sekolah hendaknya melibatkan orangtua dan masyarakat dalam proses belajar. Keterlibatan ini diharapkan akan berbuah dukungan dalam berbagai bentuk dari orangtua dan masyarakat. Kegiatan wajib: Mengadakan pameran karya siswa 
pada setiap akhirnya tahun ajaran dengan mengundang orangtua dan masyarakat untuk memberi apresiasi pada siswa.

Pelaksanaan penumbuhan budi pekerti di Sekolah tidak terlepas dari peran guru. Pada dasarnya guru merupakan :

a. pembangun citra diri positif anak

b. model atau tokoh idola

c. Mendidik dengan mencelupkan diri

d. inspirasi peserta didik

b. Menebar benih kebajikan tanpa pamrih

Peran guru tersebut menjadikan sosok guru sebagai panutan bagi peserta didik dalam kehidupan sehari-hari aik di lingkungan sekolah, keluarga maupun masyarakat. Kegiatan evaluasi perlu dilaksanakan dalam pelaksanaan penumbuhan budi pekerti di Sekolah dengan tujuan untuk memantau pelaksanaan pendidikan karakter pada peserta didik serta untuk melihat sampai pendidikan dalam membentuk karakter pada peserta didik untuk dapat memiliki pola pikir dan tingkah laku yang baik berdasarkan agama, pancasila dan norma yang berlaku di masyarakat. Kegiatan penumbuhan budi pekerti dapat dilaksanakan pada kegiatan intra kulikuler, ekstra kulikuler dan non kulikuler. Sekolah sebagai taman dalam pendidikan diharapkan mampu menginternalisasi nilai-nilai moral dan spiritual pada peserta didik. Kurikulum 2013 merupakan kurikulum yang dapat menginternalisasi nilai-nilai moral $d$ an sikap peserta didik ke dalam ranah pemelajaran. Guru memiliki peranan penuh dalam upaya mendidik, membimbing dan melatih peserta didik untuk menjadi insan yang memiliki akhlak yang baik.

\section{DAFTAR PUSTAKA}

Baswedan, A. 2015. Penumbuhan Budi Pekerti, Disampaikan dalam Rapat Koordinasi Kepala Dinas Pendidikan Propinsi se-Indonesia, Jumat, 10 Juni 2015.Jakarta: Kemendikbud RI.

Prayitno \& Manulang, B. 2011. Pendidikan Karakter dalam Pembangunan Bangsa, Jakarta: PT Grasindo

Rahmat, I. 2014. Guru Berkarakter Untuk Implementasi Pendidikan Karakter, Yogyakarta: Gava Media

Samani, M \& Hariyanto. 2011. Konsep dan Model Pendidikan Karakter. Bandung: PT Remaja Rosda Karya.

Tim Penyusun. 2011. Pedoman Pelaksanaan pendidikan Karakter: Berdasarkan Pengalaman Di Satuan Pendidikan Rintisan. Jakarta: Puskurbuk Badan Penelitian Dan Pengembangan Kementerian Pendidikan Nasional.

Tim penyusun. 2010. Bahan Pelatihan Penguatan Metodologi Pembelajaran Berdasarkan Nilai-Nilai Budaya Untuk Membentuk daya Saing dan karakter Bangsa: Pengembangan Pendidikan Budaya Dan Karakter Bangsa. Jakarta: Pusat kurikulum Badan Penelitian Dan Pengembangan Kementerian Pendidikan Nasional.

Tim Penyusun. 2010. Rencana Aksi Nasional (RAN) Pendidikan Karakter Kementerian Pendidik Nasional 2010-2014 Online), http://pendikar.dikti.go.id/gdp/wp- content/uploads/NASKAH-RANKEMENDIKNAS-REV-2.pdf, diakses 1 Mei 2011 